\title{
Revitalization of Rule of Law, Democracy and Good Governance Ideas as Modern State Pillar
}

\author{
Syafruddin Muhtamar ${ }^{1} \quad$ Anshori Ilyas $^{2} \quad$ Abdul Razak $^{3}$ \\ 1. PhD Student at Postgraduate Program, Faculty of Law, Hasanuddin University \\ 2. Doctor on Legal Science, Faculty of Law, Hasanuddin University \\ 3. Professors on Legal Science, Faculty of Law, Hasanuddin University
}

\begin{abstract}
This article aims to explain in a reflective manner the main ideas underlying the operationalization of modern state, namely Rule of Law, Democracy and Good Governance, and to revitalize these ideas in the sublimity of human soul and the urgency of state organizations nature. The rule of law, democracy and good governance as intellectual products contain distinctive modern values. Historically, these ideas have a connection with the idea in the pre-modern century, especially the Renaissance era. Three main elements of modern state pillars are the supremacy of law, government of people and economic welfare. The essence of these three elements is rooted in science which is characterized by anthropocentrism and it ignores the potential of science that is theocentric in nature. Using reflective analysis method, the rule of law, democracy and good governance are disclosed based on the essential context of human soul true needs as citizens whose existence is not merely material, but also spiritual. The analysis shows the importance of the three main pillars of modern state to be revitalized to bring it closer to the sublime needs of human soul; so that the state power organized by law can build a good system of government because the basic idea is to balance the economic and spiritual orientation of human society in the state. Therefore, it can respond to human needs as well as the pragmatic needs of a modern and balanced society.
\end{abstract} Keywords: Rule of Law, Democracy, Good Governance

DOI: $10.7176 /$ PPAR/9-4-06

Publication date: April $30^{\text {th }} 2019$

\section{Introduction}

Modern state is the ideal choice of society in managing life problems organizationally. The birth of a modern state took place in evolution: ideas, professional concepts, which were the driving elements of the process. The urgency of intellectual products as a determination of the ideal society organization that can be functioned in the process of shared life in all human affairs, becomes one of the vital elements in the process of state organizations evolution.

At the peak of evolution, several ideas became the main pillars of modern state: Rule of Law, Democracy and Good Governance. As an intellectual reflection of the situation in the era, Rule of Law, Democracy and Good Governance have their own elanvital throughout their birth in the modern century. These intellectual products encourage dynamic progress in the political and legal life of modern society.

The implementation of Rule of Law, Democracy and Good Governance in a modern state generated the basic characters of state and community organizations. In fact, the practice of these three pillars has not been able to realize the ideal truth desired. The rule of law which ideally places law as the only authority tends to become a tool of political power, both personal and group. Likewise, people's sovereignty in Democracy system is not necessarily sovereign, because normative institutions are ruled politically by officials who have relations with certain groups or interests, both pragmatic and capital interests of the party. Thus, public interest is easily deflected by the pragmatic interests of the authority.

Likewise the implementation of Good Governance; the implication is that slowly but surely the state authority is disarmed to the level where state power no longer has the ability to control the key values, which are its responsibility in maintaining citizens' true dignity and humanity. Glancing at the main motivation of corporate institutions to provide the greatest benefit to capital owners, then in the future, the state becomes administrative and authority is only an extension of the hands of strategic capital owners.

There is a cycle of interests of 'certain parties' who have the political or capital 'power', which in its operations is absolute, but it is under the veil called Rule of Law, Democracy and Good Governance. In practice, this Cycle is like a vicious circle that has haunted this system from the start, simply because a new format or form that can be a substitute model for the undesired system is needed to avoid the designation of gods and divine absolutism.

Based on these paradoxical problems, this article intends to provide a new literature on the needs of providing additional perspectives on Rule of Law, Democracy and Good Governance ideas, so that it can truly fulfill the ideal needs of the true elements or human nature of human society in the modern century. Thus, the establishment of these three pillars of the modern state can last even longer in the history of the existence of state organizations. 


\section{Discussion}

\subsection{Three Basic Concepts of Modern State Pillars}

\subsubsection{Rule of Law}

The term Rule of Law becomes a terminology in scientific study after A.V. Dicey constructed it in the 18th century: Rule of Law is a principle in constitution building that has three meanings: (1) as supremacy or superiority of law, which absolutely contradicts the influence of arbitrary power, and revokes prerogative and even power rights because of the emergence of these powers; (2) equality before the law or equal position of all society groups to the general state laws; (3) constitution as a result of general state laws containing individual rights as a result of a court or parliamentary decision (A.V. Dicey 2015).

Jimly Asshiddiqie uses the term nomocracy as a state of law equivalent. Concepts, ideals or ideas of the state of law, besides being related to the concept of rechtsstaat and rule of law, it is also related to nomocracy which comes from the words nomos and cratos. The term nomocracy can be compared with demos and cratos or kratien in democracy. Nomos means the norm, while kratos means power. The determining factor in the implementation of power is the norm or law. Therefore, the term nomocracy is related to the idea of sovereignty of law or principles of law as the highest authority (Jimly Asshiddiqie 2008).

Historically, the idea of state of law developed dynamically, Tamanaha elaborated (Tamanaha in Hamdan Zoelva 2006) two versions of the developing state of law: formal and substantive versions, each of which grew in three forms. The formal version of state of law concept begins with the concept of rule by law where law is interpreted as an instrument for government action. Then, it developed in the form of formal legality, where the concepts of law are interpreted as norms that are general, clear, prospective and definite. Whereas the latest development of the formal version of state of law concept is democracy and legality, where agreement determines the content or substance of law. On the other hand, the substantive version of state of law concept developed from individual rights, where privacy and individual autonomy as well as contracts are the most basic foundation. Then, it developed on the principle of rights to personal freedom and/or justice (dignity of man) and developed into social welfare concept containing principles of substantive, equality, welfare and continuity of the community.

\subsubsection{Democracy}

Democracy in the literature of political philosophy has a clear terminological definition. Etymologically, demos-cratein or demos-cratos (democracy) means a system of government from, by, and for the people or government by the people (Miriam Budoardjo 2010).

There are several characteristics of a democracy-based country according to Hans Kelsen. Those include: (1) the will of the majority and the will of the minority; (2) the will of the majority cannot be absolute domination; (3) there is a compromise between the will of the majority and the will of the minority in dealing with a problem and in the formation of a system; (4) there is no coercion in religion and belief; (5) freedom of speech, freedom of the press, and freedom of expressing opinion are guaranteed, either through the constitution or through customary agreements that occur in a state; (6) a healthy compromise makes no clash of interests between the will of the majority and the will of the minority which usually leads to anarchy (Hans Kelsen in Talhah 2009).

According to Andrew Heywood, there are several perceptions about democracy: liberal, conservative, socialist, anarchist, fascist, and ecological. The following is Andrew's description of democracy based on each perspective (Andrew Heyhood 2016).

\subsubsection{Good Governance}

Governance is the adjective of govern, which is interpreted as the action of manner of governing or action (implement), procedure of control. As a word, governance is not a new term. In 1590, this word was understood as a state of being governed, developed into a mode of living (1600), then became the office, function, or power of governing (1643), developed into a method of management, system of regulation (1660) and later on was standardized into the action or manner of governing. Therefore, it means to rule with authority. The implementation is commonly referred to as government, which in addition has a narrow meaning as an action of ruling and directing the affairs of a state. Thus, government is identical with management or administrators with specific meaning or state administrators (Nugroho D. Riant 2004).

Good governance in question is a process of administering state power in providing public goods and services called governance (government), while its best practice is called 'good governance'. In order for 'good governance' to work properly, it requires the commitment and involvement of all parties, namely the government and society. Effective good governance demands good and integrated 'alignment' (coordination), professionalism and high work ethic and morals. Therefore, the application of 'good governance' concept in the implementation of the power of state governance is a challenge (Serdamayanti 2003).

The principles of good governance for a public organization even on a scale of a state are broad. According to UNDP, there are synergistic and constructive relationship between the State, private sectors and community consisting of nine main characteristics of Good Governance: (1) Participation; (2) Application of 
Law (Fairness); (3) Transparency; (4) Responsiveness; (5) Orientation (Consensus Orientation); (6) Equity; (7) Effectiveness; (8) Accountability; (9) Strategic Vision (Tangkilisan and Hessel Nogi 2005).

\subsection{Revitalization of Three Modern State Pillars Ideas}

\subsubsection{The Philosophical Dilemma of Determining Supremacy of Law in Rule of Law Concept}

The idea of rule of law, justifies law that divides power to eliminate the bad nature of power (absolutism and feudalism) by dividing power through law, so that power becomes limited to certain authorities, thus the tendency to abuse absolute and feudal power can be avoided.

According to Tamanaha, the formal conception of state of law is aimed at the way in which the law is announced (by the authorities), the clarity of norm and temporal dimension of the enactment. Formal conception of state of law is not aimed at resolving legal decisions over the reality of the law itself, and is not related to whether the law is good or bad. Whereas the substantive conception of state of law moves more than that, while still acknowledging the formal attributes mentioned above. The conception of substantive state of law would like to move further than that. The basic rights or its derivations are basically the concept of substantive state of law. The concept is used as a foundation which is then used to distinguish between good law that fulfills these basic rights and bad law that ignores basic rights. The formal concept of state of law focuses on the feasibility of legal sources and their forms of legality, while the substantive concept includes requirements regarding the contents of legal norms (Tamahana in Hamdan Zoelva 2009).

What is said to be a philosophical dilemma in the determination of law as commander in the idea of rule of law is that law as the main basis of state power building that is or contains consensus-based ideas of what is called 'truth, justice, prosperity, happiness and will of people, which have been constructed in philosophical ideas or concepts and then transformed into legal norms, then promulgated as a regulation for the entire community. This is the dilemma, when state law acts as the 'ruler' in the real sense, but this ruler, may only manifest if the content is a consensus made by law makers, both the judiciary and the legislature, and announced or run with the political authority of state power.

This means that law as a 'ruler' has the potential to become a 'toy' for non-formal power. The power that has the most potential to play it is the individuals who made the law, who can claim consensus due to their authority. Finally, the law which is intended to be the 'ruler' or 'commander', contains non-neutrality of values in it, because all of them are constructions of values that are considered to be understood and justified by the public, which may not fit the true nature of society. Vice versa, the value instilled in the law that will be used as the 'ruler', is a value that is more of an 'understanding' desired by the legislator, and abstracts it as a general truth. This means that the legal truth in the rule of law version is subjectively placed on the truth of law makers' reasoning construct which is then called the general truth and is universalized.

\subsubsection{Ambiguity of the Meaning of Truth in the Qualitative Representation of the Majority of Democratic} Systems

Democracy stores fundamental weaknesses internally. The concept of Western democracy has many connotations and variations, is evolutionary and very dynamic so that this concept is very difficult to understand. In the 19th century, liberals often perceived democracy as a threatening and dangerous concept. The main problem for liberals is that democracy can develop into an enemy of individual freedom and pluralism (Ahmed Vaezi 2006).

As described by Abul A'la Al-Maududi, the most popular practice of sovereignty is the iron law of oligarchy. Ruling groups work together to determine various political, economic, social and cultural policies without accommodating people's real aspirations. These rulers always try to extend, monopolize and preserve their power by covering certain ideologies under the pretext of national consensus. The majority of voice that becomes the basis of democracy can fall into fatal mistakes. The propaganda machine that has been prepared by the government can create a majority that has been regulated (Abul A'la Al-Maududi 1988).

The basic value of democracy in the majority of truth; philosophically, this determination is difficult to prove empirically if the truth to be assessed is in the form of concept, idea, will or aspiration. It is because truth comes from individuals, instead of 'society'. The most correct concept, idea, will or aspiration that exists between individuals is approved by 'many people'. So this 'approving' context recognizes the value of 'truth' in democracy. What is agreed upon is the 'individual' truth. Because there are a lot of agreements, the 'truth' transforms into a 'belonging' of the majority.

This is the dilemma of the concept of democracy. If an individual who expresses a concept, idea, will or aspiration is someone who has authority in the eyes of the public, then the potential for obtaining majority approval is greater. In this position, democracy is easily manipulated for certain purposes. This means that the 'individual' truth is then claimed as a general truth, with which democracy can be accepted as justified while justifying a process. So the ambiguity of democracy truth is evident here: an 'individual' truth becomes a 'mass' truth. 


\subsubsection{Basic Danger of Economic Motives in Good Governance Idea}

Looking at the basis of good governance idea, it is understandable that this concept is rooted in the business world, which substantial objective is economical, or philosophically the main motive is above materialism. The idea of good governance to be used as a model of state management can fundamentally damage the sublime vision of the nature of state existence for humans, because this kind of management only shapes society based on materialism and capitalism.

The good governance model changes the management of state organization like managing a business organization. In the long run, the state experiences a systematic weakening to the level where state power is permanently absorbed into the economic-based or capital-based power as 'corporate-state'. What can be imagined is the return of the feudal power nuances and even the brief existence of absolutism, where the acceptance by the community occurs because people do not feel oppression as they are blinded by economic welfare.

This is what is meant in this section as the basic danger economic motive in the good governance idea. In a separated analysis, the good governance idea is philosophically feasible to revitalize if we want to give a deep nuance to this practical concept. The reason is because the state is constitutionally bound to its citizens as humans, where state power must be devoted, not tied to the corporate capital holders. If the power is handed over to serve the investors, then a major danger threatens human society as citizens. Eliminating the essence of social organizations power means that there is no place for human to seek not only economic benefits, but also spiritual happiness in a balanced way.

\section{Closing}

The theoretical basis of the modern state known in the Rule of Law, Democracy and Good Governance, fundamentally requires the expansion of the spectrum so that it can reach the foundations of the relationship between law, human and nature. Revitalization of these three pillars concept is needed, because the basis of idea contained in the three modern state pillars concept only traverses the truth of logocentrism and has not considered theocentrism. This revitalization is primarily related to the essential law that conforms to the sublime nature of human soul, so that the acceptance of state law enables the establishment of a strong legal position as commander, because the legal norms or values are not only rational, but also place human as well as spiritual truth. In the end, the three modern state pillars concept can answer the needs of human nature as well as the pragmatic needs of modern humans in a balanced and intact manner.

\section{References}

A.V. Dicey, (2015). Pengantar Studi Hukum Konstitusi. Bandung: Nusamedia.

Anrew Heyhood, (2016). Ideologi Politik Sebuah Pengantar. Jogyakarta: Pustaka Pelajar.

Ahmed Vaezi,(2006). Agama Politik: Nalar Politik Islam. Jakarta: Citra.

Abul A'la al-Maududi, (1988). Khilafah dan Kerajaan. Bandung: Mizan.

Jimly Asshiddiqie, (2008). Pokok-Pokok Hukum Tata Negara Indonesia Pasca Reformasi. Jakarta: Bhuana Ilmu Populer.

Hamdan Zoelva, (2009), Negara Hukum Dalam Perspekif Pancasila. [Online] Available:https://hamdanzoelva.wordpress.com (April 3, 2018)

Muhammad Tahir Azhary, (2003). Negara Hukum, Suatu Study tentang Prinsip-prinsipnya Dilihat dari Segi Hukum Islam, Implementasinya pada Periode Negara Madinah dan Masa Kini. Jakarta: Kencana, (Edisi Kedua).

Mochtar Mas'oed, (1999). Negara, Kapital dan Demokrasi. Yogyakarta: Pustaka Pelajar.

Miriam Budoardjo, (2010). Dasar-Dasar Ilmu Politik. Jakarta: Gramedia.

Nugroho D. Riant, (2004). Kebijan Publik, Formulasi Implementasi dan Evaluasi. Jakarta: Gramedia.

Serdamayanti, (2003). Good Governance Dalam Rangka Otonomi Daerah. Bandung: Mandar Maju.

Talhah, (2009). Teori Demokrasi Dalam Wacana Ketatanegaraan Perspektif Pemikiran Hans Kelsen, Jurnal Hukum, No. 3 Vol. 16, 418-431.

Tamanaha, Brian Z, (2006). On The Rule of Law, History, Politics, Theory. Cambridge: University Press.

Tangkilisan, Hessel Nogi S, (2005). Manajemen Publik. Jakarta: Grassindo.

Oemar Seno Adji, (1980). Peradilan Bebas, Negara Hukum, Jakarta: Erlangga. 